\title{
ULOGA OPISA VODENIH ZNAKOVA PRI OBRADI STARE I RIJETKE GRAĐE
}

\author{
THE ROLE OF WATERMARK DESCRIPTIONS \\ IN THE ANALYSIS OF OLD AND RARE MATERIAL
}

\author{
Marijana Tomić \\ Odjel za informacijske znanosti \\ Centar za istraživanje glagoljaštva \\ Sveučilište u Zadru \\ mtomic@unizd.hr

\section{Laura Grzunov} \\ Odjel za informacijske znanosti \\ Sveučilište u Zadru \\ lgrzunov@unizd.hr
}

UDK / UDC: [09:676.026.22]:025.3

Izvorni znanstveni rad / Original scientific paper

Primljeno / Received: 31. 8. 2020.

Prihvaćeno / Accepted: 22. 10. 2021.

\section{Sažetak}

Cilj i svrha. Rezultati istraživanja vodenih znakova mogu značajno pridonijeti opisu stare i rijetke građe, npr. datirati nedatirane rukopise, pomoći pri određivanju bibliografskog formata, identificirati razdoblje i mjesto (pre)uveza i sl., ali i omogućiti bolje razumijevanje konteksta proizvodnje i dijela životnog ciklusa stare i rijetke građe. Cilj je ovoga rada prikazati ulogu filigranologije u opisu stare i rijetke građe u svrhu prijedloga bilježenja podataka o vodenim znakovima pri opisu stare i rijetke građe $u$ hrvatskim katalozima.

Pristup /Metodologija. U radu je prikazan pregled literature iz područja uloge filigranologije u bibliografiji i opisu stare i rijetke građe te provedena sadržajna analiza kataloga stare i rijetke građe koji u opisima bilježe podatak o vodenom znaku kako bi se s jedne strane pružio uvid u primjere dobre prakse, a s druge strane uočile prednosti

Vjesnik bibliotekara Hrvatske 64, 2(2021), 107-131

ISSN 0507-1925 
bilježenja tih podataka u katalozima. U radu se predstavlja model povezivanja kataloga rukopisa i kataloga vodenih znakova koji je osmišljen i primjenjuje se u sklopu projekta "Pisana baština".

Rezultati ovog rada ogledaju se u boljem razumijevanju uloge vodenog znaka u opisu stare i rijetke građe te argumentiranju prednosti uključivanja tih podataka u opis stare i rijetke građe u hrvatskim katalozima. U radu je predložen način navođenja podataka o vodenim znakovima u opisu rukopisa i stare knjige kakav se primjenjuje u sklopu projekta "Pisana baština", a koji omogućuje kontekstualizaciju podataka o pisanoj baštini i istraživanja pisane baštine uz uporabu digitalnih metoda i alata.

Ograničenja Model povezivanja kataloga rukopisa i kataloga vodenih znakova prikazan u ovom radu primijenjen je na korpusu glagoljskih rukopisa i vodenih znakova pronađenih u glagoljskim rukopisima. U daljnjim fazama istraživanja valjalo bi ga primijeniti na druge vrste rukopisa i starih knjiga.

Originalnost/vrijednost ovog rada je u ukazivanju na važnost bilježenja podataka o vodenim znakovima u opis rukopisa i stare tiskane građe jer to pridonosi dataciji nedatiranih vrijednih starih i rijetkih knjiga, boljem poznavanju i razumijevanju uzusa proizvodnje rukopisa i stare tiskane građe, ali i rasvjetljuje druga pitanja o povijesti knjige i nakladništva.

Ključne riječi: vodeni znak, filigranologija, stara i rijetka građa, katalogizacija

\section{Abstract}

Aim and purpose. The results of watermark research can significantly contribute to the description of old and rare material, e.g. date undated manuscripts, help determine bibliographic format, identify period and place of (pre) binding, etc. The aim of this paper is to show the role of filigranology in describing old and rare materials for the purpose of proposing the inclusion of data on watermarks in the description of old and rare materials in Croatian catalogs.

Approach/Methodology. The paper presents an overview of the literature on the role of filigranology in the bibliography and description of old and rare material and a content analysis of catalogs of old and rare material that include watermark data in their description in order to provide insight into examples of good practices, and on the other hand to point out the advantages of recording this type of data in catalogs. The paper presents a model of including watermark data in the description of old and rare material as designed and applied within the "Written Heritage" project.

Results. The results of this paper are reflected in a better understanding of the role of the watermark in the description of old and rare material and the argumentation on the advantages of including this data in the description of old and rare material in Croatian catalogs. The paper proposes a model of including data on watermarks in the description 
of manuscripts and old books as applied in the "Written Heritage" project, which allows contextualization of written heritage data and research of written heritage using digital methods and tools.

Limitations. The model of linking the manuscript catalog and the watermark catalog presented in this paper was applied to the corpus of Glagolitic manuscripts and watermarks found in Glagolitic manuscripts. In further stages of research, it is planned to apply the model to other types of manuscripts and old books.

The originality /value of this paper is in pointing out the importance of including watermark data in the description of manuscripts and old printed materials in a way that can contribute to the dating of undated valuable old and rare books, to better knowledge and understanding of manuscripts and old printed materials, but also to other issues of book history and publishing.

Key words: watermark, filigranology, old and rare material, cataloguing

\section{Uvod}

Papir je zasigurno jedan od najvećih čovjekovih izuma. Unatoč tehnološkoj revoluciji koja traje već više desetljeća i koja je iznijela mnoge zamjene papiru u pogledu transmisije tekstova, valja ipak zaključiti da su nove tehnologije papir zamijenile samo djelomično. Dapače, mnogim se istraživanjima potvrđuje da, unatoč tehnološkom napretku ,globalna industrija papira, kao i nakladnička industrija, nisu u krizi ili padu, nego naprotiv, u stalnom porastu“".

Istraživanja papira značajno pridonose poznavanju povijesti knjige, pismenosti i kulture uopće. Osobita je njihova uloga u istraživanjima i opisu rukopisa i stare i rijetke građe općenito. Istražujući papir te sagledavajući rezultate tih istraživanja u kontekstu opće povijesti knjige i koristeći ih u svrhu utvrđivanja brojnih obrazaca o proizvodnji knjige, N. Harris informacije koje dobivamo iz papira smatra dokazima iz kojih se crpe vjerodostojni podaci o povijesti knjige i pismenosti. ${ }^{2} \mathrm{~A}$ upravo su takvi vjerodostojni dokazi o razdobljima života knjige od njezina planiranja i proizvodnje do uveza i uporabe ono što na rukopisima i starim knjigama otkrivaju, opisuju i tumače katalogizatori stare i rijetke građe, odnosno bibliografi.

Jedno od važnih obilježja ručno rađenih papira europskog podrijetla jesu vodeni znakovi. Vodeni znak ili filigran svojevrstan je zaštitni znak proizvođača papira, a prisutan je na papiru kao otisak znaka fino izrađenog od metalne žice koja se

1 Bland, M. A. Guide to early printed books and manuscripts. Oxford: Wiley-Blackwell, 2013. Str. 22.

2 Harris, N. Paper and watermark as bibliographical evidence. Lyon: Institut d' Histoire du Livre, 2017. Str. 9. 
stavljala u papirnu masu prije nego što se papirna masa ulivena u kalup osušila. ${ }^{3}$ Istraživanja vodenih znakova provode se u okvirima filigranologije, pomoćne povijesne znanosti koja svojim nalazima značajno pridonosi boljem razumijevanju i rasvjetljavanju brojnih nedoumica vezanih uz rukopise pisane na papiru i stare tiskane knjige. Gledano iz motrišta bibliografije i povijesti knjige, najčešća pitanja na koja filigranologija može odgovoriti jesu datiranje nedatiranih rukopisa, utvrđivanje vjerodostojnosti podatka o godini proizvodnje ili tiska nedatiranih rukopisa ili tiskanih knjiga, odnosno utvrđivanje falsifikata itd. ${ }^{4}$ Opis stare i rijetke građe izuzetno je kompleksan i podrazumijeva da katalogizator, odnosno bibliograf dio informacija potrebnih za opis preuzima s predloška, dio iz vanjskih izvora kao što su bibliografije, enciklopedije i drugi referentni izvori, a važan dio informacija rezultat su pažljivog pregleda tragova proizvodnje i korištenja jedinice građe koja se opisuje te rekonstrukcije tih tragova kako bi se prikupile čim jasnije i vjerodostojnije informacije o navedenoj jedinici. Vodeni znak donosi informacije o mjestu proizvodnje papira, o tome u kojoj je tvornici, odnosno mlinu, papir proizveden te načinu i razdoblju kada je papir proizveden. Vodeni znak pomaže i pri određivanju bibliografskog formata, što je važan dio opisa stare i rijetke građe, ali i pri dataciji dokumenta te uopće pri rekonstruiranju konteksta proizvodnje rukopisa i stare knjige. Iz tih razloga sve više kataloga stare i rijetke građe, osobito kataloga rukopisa i njihovih fragmenata, u svoje opise uključuje detaljnije podatke o vodenim znakovima. Nažalost, takvi podaci u hrvatskim katalozima najčešće izostaju ili pak nisu dovoljno vidljivi.

Cilj je ovoga rada prikazati ulogu filigranologije u opisu stare i rijetke građe u svrhu prijedloga uvođenja podataka o vodenim znakovima u opis stare i rijetke građe u hrvatskim katalozima. U radu ću biti prikazan model uključivanja filigranoloških istraživanja u opis stare i rijetke građe kakav se primjenjuje pri opisu glagoljskih rukopisa u sklopu projekta "Pisana baština". ${ }^{5}$ Taj model počiva na povezivanju baza podataka rukopisa i vodenih znakova kroz zajednički informacijski

\footnotetext{
3 Više o vodenim znakovima i filigranologiji vidjeti u: Mošin, V. Filigranologija kao pomoćna historijska nauka. // Zbornik odsjeka za povijesne znanosti Zavoda za povijesne i društvene znanosti Hrvatske akademije znanosti i umjetnosti, 1(1954), str. 25-93; Mošin, V.; S. Traljić. Vodeni znakovi XIII. i XVI. Vijeka. Zagreb: JAZU, 1957.; više o istraživanju vodenih znakova u okviru Centra za istraživanje glagoljaštva Sveučilišta u Zadru vidjeti u: Tomić, M.; L. Grzunov; Ž. Eškinja. Mogućnosti i pretpostavke filigranoloških istraživanja u kontekstu istraživanja zadarske glagoljske baštine. // Vjesnik bibliotekara Hrvatske 63, 1/2(2020), str. 1-29.

4 Više o tome vidjeti u: Stipišić, J. Pomoćne povijesne znanosti u teoriji i praksi: Latinska paleografija, opća diplomatika, kronologija. Zagreb: Školska knjiga, 1972. Str. 19-20.

5 Projekt “Pisana baština” skraćeni je naziv projekta „Digitalizacija, bibliografska obrada i istraživanje tekstova zadarsko-šibenskog područja iz razdoblja do kraja 19. st. pisanih glagoljicom, bosančicom i latinicom". Projekt je financiralo Ministarstvo kulture Republike Hrvatske, Sveučilište u Zadru i Vestigia institut za istraživanje rukopisa Sveučilišta u Grazu u Austriji. Više o projektu u: Renhart, E.; M. Tomić. Digitalizacija, bibliografska obrada, istraživanje i komuniciranje zadarske pisane baštine. // Arhivi, knjižnice, muzeji: Mogućnosti suradnje u okruženju globalne informacijske infrastrukture 20(2017), str. 222-267.
} 
sustav dostupan na GlagoLabu: portalu i digitalnom laboratoriju za suradnička istraživanja i promicanje hrvatskog glagoljaštva koji se također izrađuje u sklopu projekta "Pisana baština". Projekt se provodi u okviru Odjela za informacijske znanosti i Centra za istraživanje glagoljaštva Sveučilišta u Zadru te u suradnji s Vestigia institutom za istraživanje rukopisa Sveučilišta u Grazu, u Austriji.

\subsection{Papir i vodeni znakovi}

Jedno od najvažnijih obilježja papira koji je bio proizveden u Europi jest vodeni znak. Najstariji papir orijentalnog podrijetla nije sadržavao vodeni znak, a razlog tomu D. Hunter vidi u kalupu za papir koji se izrađivao od bambusa, materijala od kojega se vodeni znak nije mogao izrađivati. ${ }^{6}$ Prvi vodeni znak pojavio se u Italiji, najvjerojatnije oko 1282. godine, a ubrzo se počinje upotrebljavati pri proizvodnji svih papira. Vodeni su znakovi predstavljali proizvođača/tvornicu papira, ali i veličinu arka i njegovu kakvoću te datum proizvodnje, zbog čega se iz vodenog znaka mogu doznati važni bibliografski podaci. Naime nakon identifikacije vodenog znaka, odnosno mlina u kojem je bio proizveden papir, s visokom se pouzdanošću može odrediti razdoblje proizvodnje papira, a pridodaju li se tomu podaci priskrbljeni kodikološkim, paleografskim i tipografskim analizama knjige, na temelju podatka o razdoblju proizvodnje papira moguće je datirati nedatirane rukopise i stare knjige. Naime s obzirom na to da mlinovi nisu mogli odjednom proizvoditi jako velike količine papira, a potražnja za njim rasla je, osobito nakon pojave tiska, smatra se da je papir bio prodan i korišten za tisak vrlo brzo nakon proizvodnje, odnosno da nije dugo stajao u skladištima. Stoga podatak o razdoblju korištenja određenog vodenog znaka može upućivati na to da je i knjiga bila tiskana otprilike $\mathrm{u}$ istom razdoblju.

U staroj knjizi gotovo uvijek se može pronaći jedan, ali često i više, čak i desetak ili više različitih vodenih znakova. Još uvijek nije pouzdano utvrđeno koji je razlog tomu što je kod knjiga tiskanih u 15. stoljeću i nešto kasnije obično prisutan tako velik broj vodenih znakova. Većina autora tvrdi da je riječ o tome da mlinovi nisu uspijevali proizvesti dovoljno papira da bi opskrbili tiskarske radionice pa je tiskar bio prinuđen papir za jednu nakladu nabavljati iz različitih mlinova. Iako ne nudi drugačiju argumentaciju za uporabu različitih papira pri tisku pojedine knjige, Hunter se s time ne slaže, tvrdeći da su mlinovi zapošljavali velik broj radnika i imali proizvodnju koja je bila dovoljno velika da je svaki mlin mogao sam opskrbiti tiskarsku radionicu. ${ }^{7}$ Najvjerojatnije odgovor na to pitanje ovisi od slučaja do slučaja, no važno je imati na umu važnost otkrivanja i dokumentiranja pojave vodenih znakova pri istraživanju rukopisa i starih knjiga jer nam ti podaci ponekad

${ }^{6}$ Hunter, D. Papermaking: The History and technique of an ancient craft. New York: Dover Publications, 2016. Str. 260.

7 Isto, str. 261. 
mogu razriješiti mnoge dvojbe ili pak svratiti pozornost na obrazac proizvodnje, kontekst u kojem su nastali ili koja druga pitanja.

\section{Filigranologija i opis stare i rijetke građe}

Pri opisu rukopisa i starih knjiga, odnosno u bibliografiji, istraživanja vodenih znakova daleko su zastupljenija od istraživanja samog papira. Pomoćna povijesna znanost koja se bavi istraživanjem vodenih znakova, filigranologija, može značajno pridonijeti bibliografiji, u smislu datacije rukopisa i starih knjiga za koje razdoblje i mjesto proizvodnje, odnosno tiska, nisu poznati, ali i određivanju bibliografskog formata ili obrazaca proizvodnje kodeksa, pa sve do širih saznanja o povijesti knjige koja se odnose na detektiranje puta papira, trgovinskih i kulturnih veza i sl. S obzirom na to da se u posljednje vrijeme pojavljuje sve više baza vodenih znakova u svijetu, istraživanja rukopisa značajno se obogaćuju mogućnostima koje proizlaze iz rezultata istraživanja papira i vodenih znakova.

U današnje vrijeme vodeni se znakovi, kada je to moguće, digitaliziraju, a digitalne reprodukcije i metapodaci nastoje se pohraniti u online dostupnim bazama podataka. To omogućuje mnoga napredna istraživanja rukopisa i stare građe jer se podaci koji se iz njih mogu iščitati stavljaju u novi kontekst na temelju podataka o vodenim znakovima. Kako bi to bilo moguće, uz digitalizaciju su potrebne standardizirane i interoperabilne baze podataka. L. Hellinga smatra da je upravo izgradnja sustava strojno čitljivih podataka, odnosno baza podataka, važna jer zaista omogućuje da činjenice smjestimo u kontekst različit od onog koji poznajemo od ranije. ${ }^{8}$

Istraživanja vodenih znakova, osobito ako se promatraju u odnosu prema ostalim tragovima proizvodnje knjiga, odnosno tragovima pisanja ili tiskarskog i knjigoveškog postupka, pridonose otkrivanju mnogobrojnih bibliografskih dokaza. J. Bidwell navodi da su znanstvenici na temelju istraživanja papira i proučavajući dokaze koji se na papiru nalaze došli do mnogih spoznaja koje se tiču pogrešnih datuma na inkunabulama i starim knjigama, otkrivali točnu kolaciju u onim rukopisima u kojima je ona bila narušena i sl. ${ }^{9}$ Dodatno, podaci o vodenim znakovima mogu uputiti i na brojne druge zaključke, npr. uputiti na uzuse proizvodnje knjige u nekom razdoblju, značajke trgovine papira i distribucijskih kanala, ali mogu otkriti i mjesto i razdoblje (pre)uvezivanja ili učvršćivanja knjiga itd.

8 Hellinga, L. A meditation on the variety in scale and context in the modern study of the early printed heritage. // The papers of the Bibliographical Society of America 92, 4(1998), str. 413.

9 Bidwell, J. The study of paper as evidence, artefact, and commodity. In Peter Davison (ed.), The Book encompassed: Studies in twentieth-century bibliography ( $\mathrm{Pp} 69-82)$. Cambridge: Cambridge University Press, 1992. 
Uz tiskano Briquetovo djelo u kojemu su popisani i opisani vodeni znakovi i koje je snažno utjecalo na razvoj filigranologije kao znanstvene discipline, ${ }^{10}$ danas je dostupna baza podataka $\mathrm{BO}$ - Briquet Online ${ }^{11}$ koju je izradila Austrijska akademija znanosti te na portalu EU projekta Bernstein - The Memory of Paper, a kao skenirani dokument dostupna je na mrežnim stranicama Međunarodne udruge povjesničara papira. ${ }^{12}$ Baza omogućuje i detaljniji opis papira, a osobitu važnost projekta čini strukturiranost podataka o vodenim znakovima koja omogućuje kvantitativna istraživanja podataka o papiru i o vodenim znakovima, vizualizaciju i rudarenje dostupnih podataka.

Osobita je važnost filigranologije pri opisu stare i rijetke građe, odnosno u bibliografiji. A. Stevenson je prvi bibliograf koji svraća pozornost na papir i vodene znakove. ${ }^{13}$ Prema P. Needhamu, Stevenson je „utemeljio znanstvena istraživanja papira kao bibliografskog dokaza“ “. ${ }^{14}$ Ono što čini njegov najsnažniji prinos bibliografiji jest detaljan opis postupaka kojima se papir u kalupima proizvodio te razlozi pojave, kao i načini razlikovanja tzv. „vodenih znakova blizanaca“15 na europskom ručno proizvedenom papiru. Upravo nakon njegovih otkrića u tome području, sva istraživanja papira u okvirima bibliografije počivaju na istraživanjima vodenih znakova. ${ }^{16}$ Poseban je Stevensonov doprinos dokaz izveden na temelju istraživanja vodenih znakova o tome da Missale Speciale nije, kako se na temelju tipografije smatralo, otisnut prije Gutenbergove Biblije, nego nakon 1473. godine. ${ }^{17}$ Takva vrijednost papira koji se može koristiti kao vjerodostojan izvor informacija o dokumentu potvrđena je na nizu važnih i raznorodnih primjera. Jedan od njih je i istraživanje kupaca, odnosno kolekcionara knjiga u Rimu u 16. st., pri kojem je za knjige jednog od kolekcionara Hobson s velikom vjerojatnošću zaključio da je knjiga bila uvezana u Rimu oko 1535. godine. Taj je zaključak izveo na temelju triju argumenata od kojih je najvažniji bio upravo taj da je kao predlist kojim su se povezivali knjižni blok i korice bio korišten papir s vodenim znakom

10 Briquet, C. M. Les Filigranes: Dictionnaire historique des marques du papier dés leurs apparition vers jusqu'en 1600. Geneva: A. Jullien, 1907. Vidi i u: Tomić, M., Grzunov, L., Eškinja, Ž. Nav. dj., str. 6.

11 BO - Briquet Online. Dostupno na: http://briquet-online.at/

12 Internatioanl Association of Paper Historians. [citirano: 2021-08-20]. Dostupno na: http:// www.paperhistory.org/Watermark-catalogues.

13 Needham, P. Allan H. Stevenson and the bibliographical uses of paper. // Studies in Bibliography, 47(1994), str. 23-64. [citirano: 2021-08-20]. Dostupno na: https://www.jstor.org/stable/40371991.

14 Needham, P. Nav. dj., str. 24.

15 Više o tome vidjeti u: Stevenson, A. Watermarks are twins. // Studies in Bibliography, 4(1951/52), str. 57-92.

16 Needham, P. Nav. dj., str. 29-30.

17 Više o tome vidjeti u: Stevenson, A. H. The problem of Missale Speciale. London: The Bibliographical Societey, 1967. 
koji je opisao Briquet i koji se u njegovom katalogu nalazi pod oznakom 6088, a za koji je poznato da se koristio u Rimu oko $1532-1585 .^{18}$

T. Tanselle, kao bibliograf, promatrajući opis stare i rijetke građe, izostanak podataka o papiru i vodenim znakovima u bibliografskom opisu smatra začuđujućim, osobito s obzirom na to da je papir materijal koji još uvijek daje oblik knjizi, odnosno čini njezin temeljni i najznačajniji dio. ${ }^{19}$ Iako neke podatke o papiru doduše nalazimo u bibliografskom opisu stare i rijetke građe, oni se većinom odnose na oštećenja i na nedostatke, a ne na sâm opis strukture, vrste i drugih značajki papira od kojega ili od kojih je knjiga izrađena. Poseban problem uočava se kod digitalizacijskih projekata kojima su obuhvaćeni rukopisi i stara i rijetka građa, a kod kojih često izostaje podatak čak i o vrsti podloge, a posebno onda o njezinu opisu te o prisutnosti i vrsti vodenih znakova.

I P. A. Gaskell u svom kapitalnom djelu Introduction to bibliography posvećuje posebnu pozornost vodenim znakovima, ističući kako ih je potrebno zabilježiti, i to ne samo njihovo postojanje, nego i poziciju na stranici. ${ }^{20} \mathrm{~S}$ obzirom na relativnu ujednačenost u pozicioniranju vodenog znaka na arku papira, na temelju njegove pozicije na stranici lakše se može se s većom sigurnošću utvrditi bibliografski format, ${ }^{21}$ koji je, prema ISBD-u, dio opisa stare i rijetke građe (element 5.3.2. Bibliografski format i dimenzije prema ISBD-u), a ponekad ga je teško bez toga sa sigurnošću utvrditi. Možemo pretpostaviti da katalogizatori koriste mogućnost utvrđivanja bibliografskog formata na temelju pozicije vodenog znaka, no podatke o samom vodenom znaku ne navode u bibliografskom opisu rukopisa i stare knjige.

Značajnu pozornost i papiru i vodenim znakovima pridaje i suvremeni priručnik M. Blanda A guide to early printed books and manuscripts ${ }^{22}$ u kojem je uz iskazivanje važnosti i uloge vodenog znaka u opisu stare i rijetke građe dan detaljan uvid u ranu proizvodnju papira, uključujući metode njegove proizvodnje, kao i trgovinu papirom. No ono što je osobito važno u Blandovu pristupu jest uključivanje u priručnik i opisa metoda analize i opisa papira i vodenih znakova te isticanje važnosti takvih istraživanja u smislu otkrivanja i razumijevanja ne samo obrazaca proizvodnje rukopisa i starih tiskanih knjiga nego i važnosti opisa i bilježenja podataka o vodenim znakovima za analizu i razumijevanje šire kulturološke slike,

\footnotetext{
18 Hobson, A. R. A. Some sixteenth-century buyers of books in Rome and elsewhere. // Humanistica Lovaniensia: Journal of Neo-Latin Studies 34A(1985), str. 69.

19 Tanselle, T. The Bibliographical description of paper. // Studies in Bibliography, 24(1971), str. 27; 28-67.

20 Gaskell, P. A. New Introduction to bibliography. Oxford: University Press, 1995. Str. 60-65.

${ }^{21}$ Bibliografski format je brojčana oznaka tiskarskih slogova u svakoj tiskarskoj formi. Usp. ISBD: Međunarodni standardni bibliografski opis. Objedinjeno izd.. Zagreb: Hrvatsko knjižničarsko društvo, 2014. Str. 206-207; 300.

22 Bland, M. A. Nav.dj., str. 23-48.
} 
trgovine i trgovačkih putova, nakladništva i drugih okolnosti bitnih za povijest knjige. Bland upućuje i na važnost standardizacije opisa vodenih znakova, osobito u smislu razmjene podataka o vodenim znakovima, pozivajući se na propise koje objavljuje Međunarodna udruga povjesničara papira koja je 2013. godine objavila Međunarodni standard za registraciju papira s vodenim znakovima ili bez njih. ${ }^{23}$ Riječ je o preradbi standarda iz 1997. godine kako bi se adresiralo promjene i nove mogućnosti baza vodenih znakova uzrokovane razvojem i primjenom informacijskih tehnologija u području povijesti papira i filigranologiji. Upravo taj standard u uvodnome dijelu ozbiljno upozorava na praksu prema kojoj, zbog povećanja zanimanja za vodene znakove, mnoge ustanove počinju opisivati i digitalizirati vodene znakove, no prema vlastitim kriterijima i smjernicama.

Analitička bibliografija knjigu promatra kao materijalni objekt, tražeći na njoj i u njoj dokaze o njezinoj proizvodnji, provenijenciji, putu koji je prošla od proizvodnje, odnosno tiska do posljednjeg vlasnika itd. W. P. Williams i C. S. Abbott navode važnost tragova koji se na knjizi javljaju i koje bibliografi interpretiraju, no ipak upozoravaju na nedostatne dokaze, kao i na one koji su međusobno u konfliktu, što često ometa zaključivanje ili ga upućuje u pogrešnom smjeru. ${ }^{24}$ Svakako to moramo uzeti u obzir i pri analizi vodenih znakova koji, iako su sami po sebi snažan dokaz u području proizvodnje rukopisa jer upućuju na obrasce u proizvodnji, kao i na okolnosti proizvodnje rukopisa, mogu uputiti na veze između glavnih dionika u proizvodnji, npr. tiskara, nakladnika, naručitelja i sl., ali i na šire trgovačke, kulturne i političke veze. Ipak valja imati na umu da su vodeni znakovi jedan od mnoštva dokaza koje rukopisi i stare knjige nose te da se ti dokazi moraju sagledati u širem kontekstu, odnosno s dokazima koji proizlaze iz cjelokupnog kodikološkog, paleografskog, tipografskog, ali i povijesnog i drugih istraživanja uobičajenih u povijesti knjige, kao što su ona koja ne koriste samu knjigu kao izvor, već dokaze o knjizi crpe iz izvora izvan knjige, kao što su arhivski zapisi tiskara i nakladnika i sl. ${ }^{25}$

$\mathrm{N}$. Harris prednosti istraživanja papira u okvirima bibliografije vidi u dvjema činjenicama: (1) papir sadrži informacije (dokaze) koje su vjerodostojne i pouzdane i (2) istraživanja papira i vodenih znakova u pravilu nisu skupa, odnosno i uz opremu koja nije osobito skupa može se dobiti niz podataka važnih za bibliografski opis određenog primjerka. Unatoč tomu Harris upozorava na to da je potrebno veliko znanje da bi se podaci koji se dobiju na taj način interpretirali pravilno, a sam posao istraživanja vodenih znakova uz znanje zahtijeva i vrijeme

23 International Standard for the Registration of Papers with or without Watermarks. Version 2.1.1. / International Association of Paper Historians, 2013. [citirano: 2020-06-20]. Dostupno na: http://www.memoryofpaper.eu/products/IPHN2.1.1_en.pdf.

${ }_{24}$ Usp. Williams, W. P.; C.S. Abbott. C. An introduction to bibliographical and textual studies. Kindle ed. New York: The Modern Language Association of America, 2009.

25 Usp. Isto. 
i strpljenje. ${ }^{26}$ Riječ je zapravo o tome da su podaci o vodenim znakovima tim više upotrebljivi čim ih je više obrađeno i dostupno, a upravo to, uz pojedinačna istraživanja, zahtijeva vrijeme i strpljenje. No s druge strane rezultati istraživanja vodenih znakova mogu biti, i često jesu, ključni čimbenik kod mnogih istraživanja starih i rijetkih knjiga. Zbog toga valja posebno istaknuti Harrisov stav s kojim se osobito slažemo:

„...dokazi koji proizlaze iz papira nikada ne smiju biti izolirano sagledavani. Oni moraju biti spojeni i uklopljeni među ostale vrste dokaza koje nosi fizički artefakt, bilo da je riječ o rukopisu ili otisku tiskane forme, dokazima koji se pronalaze na uvezu, anotacijama čitatelja i ostalim sitnim, čudnovatim, malenim komadićima dokaza koje kodikolog ili bibliograf uče promatrati, mjeriti i dokumentirati. “' 27

Naime bibliografski opis stare i rijetke građe, bilo da je riječ o rukopisima ili o starim knjigama, zaista često zahtijeva forenzičke sposobnosti, interdisciplinaran pristup i čitanje različitih tragova skrivenih u papiru, načinu uveza, koricama, pismu, bilješkama, podacima o bivšim vlasnicima, knjižarima, tiskarima itd. Pročitati pojedini trag najčešće nije dovoljno, kao niti pročitati i zasebno interpretirati pojedine tragove. Bibliografov je uspjeh u interdisciplinarnom pristupu i tumačenju svih otkrivenih tragova u ukupnosti. Podaci prikupljeni na temelju filigranoloških istraživanja mogu biti pravilno i potpunije interpretirani uz uvid u rezultate kodikoloških, paleografskih, tipografskih i drugih istraživanja. Integracija metoda iz navedenih disciplina uz uporabu digitalnih tehnologija u današnje se vrijeme osobito razvija u okvirima digitalne humanistike, i to posebno metodama tzv. arheologije knjige i knjižne forenzike. Ako se rezultati istraživanja vodenih znakova promatraju u odnosu prema ostalim tragovima proizvodnje knjiga, odnosno tragovima pisanja ili tiskarskog i knjigoveškog postupka, mogu značajno pridonijeti otkrivanju mnogobrojnih bibliografskih dokaza.

Pri katalogizaciji stare i rijetke građe uobičajeno je da se podaci o knjizi često traže u raznim izvorima, onima sadržanim u samoj knjizi i onima izvan nje. Koristeći se rezultatima istraživanja vodenih znakova, bibliograf nastoji utvrditi neke od podataka o knjizi koje bi bez toga bilo puno teže ili nemoguće otkriti, npr. je li knjiga napisana ili otisnuta one godine koja je na njoj otisnuta ili joj se pripisuje ili u koje druge vrijeme. Institut za povijest knjige iz Lyona u Francuskoj u današnje vrijeme najviše istražuje uporabu istraživanja papira i filigranologije u bibliografiji, a u svojim istraživanjima papira utvrđuju kako bibliografska analiza doduše počiva na pretpostavci o tome da postoji korelacija između vremena i mjesta na kojem je papir proizveden i vremena i mjesta gdje se je koristio, iako upozoravaju

26 Harris, N. Nav.dj., str. 7.

27 Isto, str. 8. 
na to da tu pretpostavku valja shvatiti oprezno. S oprezom također valja interpretirati uporabu različitih papira u istom izdanju ili pak istoj knjizi. ${ }^{28}$

$\mathrm{Na}$ ulogu filigranologije u kodikološkom opisu upozorava i B. Wagner koja istraživanja vodenih znakova smatra važnim dijelom bibliografske analize, upravo stoga što saznanja o njima mogu pomoći u rekonstrukciji načina proizvodnje određene knjige, ali i pomoći pri njezinoj dataciji. ${ }^{29}$

\section{Bilježenje podataka o vodenim znakovima u katalozima stare i ri- jetke građe}

Zahvaljujući svojoj velikoj informacijskoj vrijednosti pri istraživanju rukopisa, podaci o vodenim znakovima u najvažnijim se katalozima rukopisa i fragmenata bilježe vrlo pažljivo i detaljno.

\subsection{Primjeri dobre prakse iz referentnih međunarodnih kataloga}

Ovdje će biti prikazana četiri primjera dobre prakse iz referentnih međunarodnih kataloga.

\section{Primjer 1. Katalog E-codices}

Projekt „E-codices“ u okviru kojeg se razvija referentni skupni katalog rukopisa započeo je 2005. s ciljem digitalizacije, opisa i virtualnog okupljanja te otvorenog pristupa svim srednjovjekovnim i odabranim modernim švicarskim rukopisima. ${ }^{30}$ Budući da je standardizacija opisa rukopisa na međunarodnoj razini inače problematična zbog brojnih razloga, upravo su strukturiranost opisa i elementi opisa koji se koriste u projektu postali svojevrstan obrazac za opise rukopisa i u drugim katalozima, odnosno informacijskim sustavima. U značajnom broju zapisa u katalogu E-codices navode se podaci o vodenim znakovima. Ovdje se donosi primjer opisa rukopisa Hippocrates, Aphorisms iz 15. st. iz zbirke Braginsky iz kojeg je vidljivo da je riječ o rukopisu koji je katalogizator datirao upravo prema vodenom znaku, što izričito navodi u napomeni: „Datiranje se temelji na identifikaciji vodenog znaka u papiru.“ (slika 1).

\footnotetext{
28 Institut d' historie du Livre. Paper Studies. [citirano: 2020-06-25]. Dostupno na: ihl.enssib.fr/ analytical-bibliography-an-alternative-prospectus/paper-studies.

29 Wagner, B. Introduction. // Early printed books as material objects: Proceedings of the Conference Organized by the IFLA Rare Books and Manuscripts Section, Munich, 19-21 August 2009. / edited by B. Wagner and M. Reed. Hague: De Gruyter Saur, 2010. Str. 1.

30 E-codices - Virtual Manuscript Library of Switzerland. [citirano: 2020-06-20]. Dostupno na: https://www.e-codices.unifr.ch/en.
} 


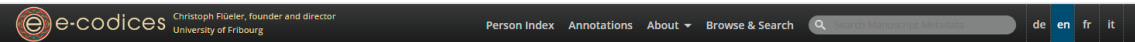

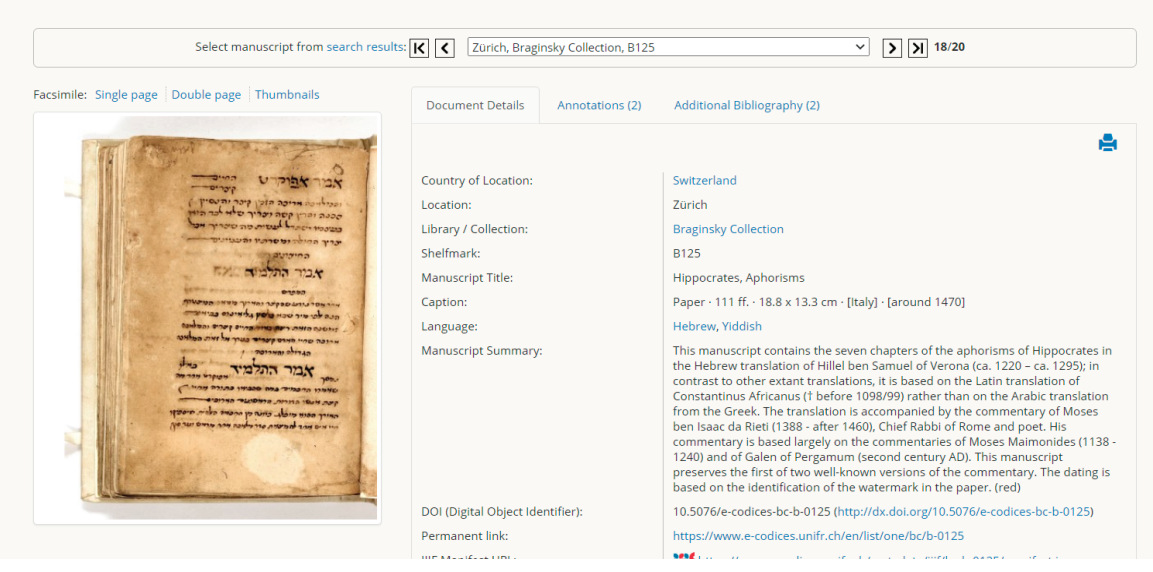

Slika 1. Primjer kataložnog zapisa koji sadrži opis vodenog znaka iz kataloga E-codices. Izvor: E-codices, zapis dostupan na: https://www.e-codices. unifr.ch/en/searchresult/list/one/bc/b-0125.

Primjer 2. Međunarodna baza podataka fragmenata, Fragmentarium

Podaci o vodenim znakovima osobito su važni pri opisu fragmenata rukopisa i starih knjiga. Naime fragmenti inače podliježu izuzetno detaljnom opisu jer o bogatstvu elemenata opisa fragmenata ovisi mogućnost okupljanja fragmenata koji su pripadali istoj izvornoj kodikološkoj jedinici. Vrsta podloge, a kada je riječ o papiru i vrsta papira, svakako je jedan od elemenata opisa koji takva okupljanja omogućuju, pa se podatak o vodenom znaku preporučuje pri opisu fragmenata. Fragmentarium, najveća međunarodna baza podataka fragmenata, također se izrađuje u sklopu projekta „E-codices“. U opis fragmenta uvijek uključuje podatak o vodenom znaku kada se on može pronaći, odnosno identificirati.

Tako je u opisu fragmenta Book of prayer (Ms. fr. 4.15), 1475-1525 $5^{31}$ (slika 2) navedeno sljedeće:
„Vodeni znak je djelomično vidljiv; kruna od ljiljana na vrhu, iznad štita, od kojih je vidljiva samo dvostruka fleur-de-lis. Najsličniji je dvama vodenim znakovima pronađenim u dokumentima koji se na- laze u Trieru, vidi: G. Piccard, Wasserzeichen Lilie. Findbuch XIII (Stuttgart 1983) 277, nrs 1712 en 1713. Oba vodena znaka proizve- dena su 1516.“ (prijevod autoricâ).

\footnotetext{
31 Fragmentarium: Laboratory for Medieval Manuscript Fragments. Book of prayer. [citirano: 2021-08-20]. Dostupno na: https://fragmentarium.ms/description/F-mnhb/4066.
} 


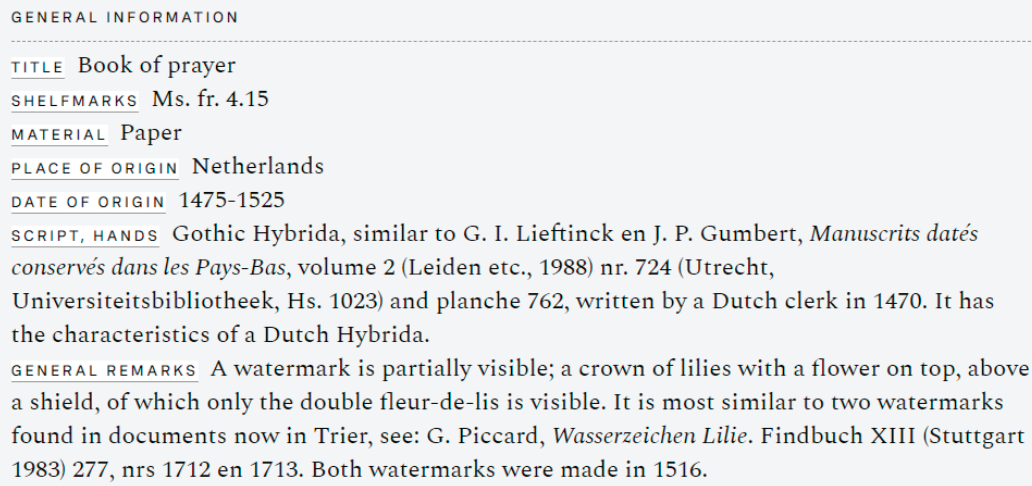

Slika 2. Primjer dijela opisa fragmenta Book of prayer (Ms. fr. 4.15), 1475-1525, u bazi podataka Fragmentarium

Osobito je u opisu fragmenata značajan primjer korištenja podataka dobivenih iz analize vodenih znakova za datiranje uveza knjiga, ali i uvrštavanje analiza vodenih znakova i zaključaka na koje upućuju u obliku slobodnog teksta. Primjer prikazan na slici 3 povezuje vodeni znak s razdobljem uveza, odnosno preuveza knjige. Vodeni znak na papiru identificiran je u predlistu uvezane knjige te su podaci uvršteni u opis fragmenta Gradual (Palm Sunday), F-IOax, koji se čuva u Bodleian Library u Oxfordu, a koji je korišten kao uvez jedne od inkunabula. Riječ je o fragmentu Graduala koji je nepoznati njemački knjigoveža u 19. st., odnosno oko 1830. godine koristio kako bi preuvezao jednu inkunabulu. Valja istaknuti da je riječ o jednom od sedam fragmenata koji su pripadali istom kodeksu, a koje je isti knjigoveža koristio za ojačavanje uveza pri preuvezivanju više svezaka. ${ }^{32}$

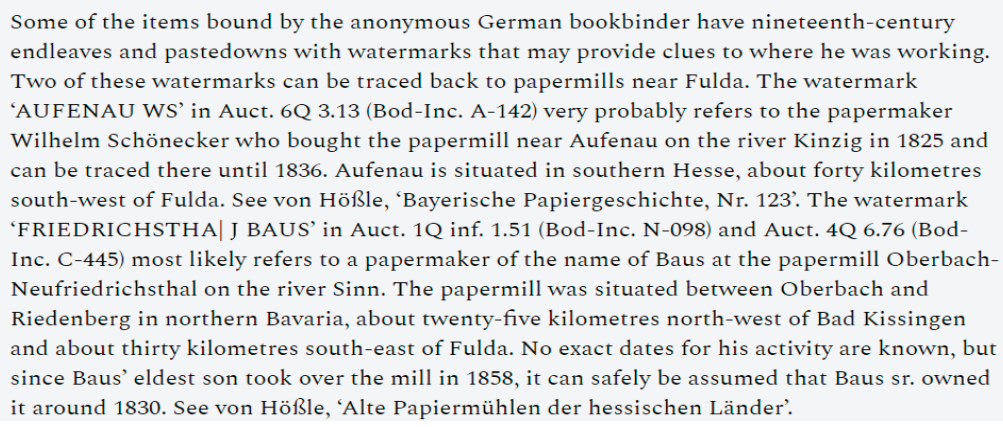

Slika 3. Primjer opisa fragmenta Gradual (Palm Sunday) iz baze Fragmentarium u kojem se spominje vodeni znak i razdoblje uveza knjige

32 Fragmentarium: Laboratory for Medieval Manuscript Fragments. Gradual (Palm Sunday) [citirano: 2021-08-20]. Dostupno na: https://fragmentarium.ms/description/F-10ax/378. 
U napomeni je navedeno da neki od primjeraka koji su bili uvezani kod anonimnog njemačkog knjigoveže imaju pri preuvezu dodane papire s vodenim znakovima na kojima se mogu pronaći tragovi koji upućuju na to gdje je i kada knjigoveža radio. Dva od tih vodenih znakova mogu se povezati s papirnicom blizu Fulde i vrlo vjerojatno pripadaju proizvođaču papira Wilhelmu Schoneckeru koji je kupio papirnicu blizu Aufenaua na rijeci Kinzig 1825. godine, a rad se može pratiti do 1836. godine. Idući vodeni znak povezuje se s proizvođačem Bausom koji je radio u papirnici Oberbach-Neufriedrichsthal na rijeci Sinn. Nije poznato točno vrijeme kada je taj mlin radio, no poznat je podatak da ga je godine 1858 . preuzeo najstariji Bausov sin, pa se može pretpostaviti da je mlin bio u njihovom posjedu otprilike od 1830. godine. Dakle podaci koji se dobivaju iz vodenih znakova u ovom su slučaju uspješno korišteni u datiranju preuveza, odnosno posredno i u dataciji korištenja fragmenta pergamene kao uveza inkunabule. Zanimljiv je to primjer koji jasno upućuje na to da je identifikacija i opis vodenih znakova na papiru koji pripada izvornoj jedinici ili je pak u nju ugrađen prilikom preuveza, uvijek vrijedan podatak koji u procesu knjižne forenzike može značajno pridonijeti identifikaciji ne samo razdoblja kada je knjiga pisana ili tiskana nego i agenata koji su sudjelovali u bilo kojem dijelu životnog ciklusa knjige, bilo da je riječ o njezinu tisku, uvezu ili kojoj drugoj aktivnosti.

\section{Primjer 3. Projekt „Commentaria in Aristotelem Graeca et Byzantina“}

Podaci o vodenim znakovima vrlo se često navode u onim bazama podataka starih knjiga i rukopisa koje nastaju u sklopu projekata čiji istraživački korpus čini takva građa. Primjer je projekt „Commentaria in Aristotelem Graeca et Byzantinai“, čiji je rezultat i katalog u čijim se zapisima nalaze detaljni podaci o vodenom znaku sadržanom u rukopisu, pri čemu se obavezno navodi podatak o lokaciji vodenog znaka te referentni izvor, odnosno katalog u kojem se vodeni znak navodi i njegova oznaka unutar kataloga (slika 4).

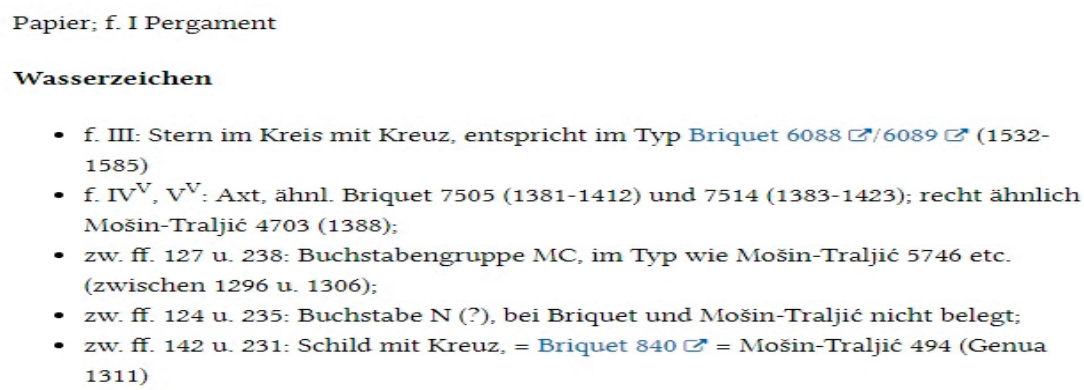

Slika 4. Primjer dijela kataložnog zapisa koji sadrži navode vodenih znakova iz kataloga Commentaria in Aristotelem Graeca et Byzantina 


\section{Primjer 4. Katalog Morgan Library \& Museum}

Zastupljenost podataka o vodenim znakovima vidljiva je i na primjeru zapisa preuzetog iz kataloga Morgan Library \& Museum. U primjeru prikazanom na slici 5 zamjetno je da bibliograf nije potpuno siguran o kojem je vodenom znaku riječ, pa navodi nekoliko mogućnosti: Heawood 3885, datiran u Rim 1555., ili Briquet 6088, 6089, Rim 1535., Fabriano 1585. No valja uočiti da, iako nije bilo moguće odrediti o kojem je vodenom znaku riječ, bibliograf ne izostavlja taj podatak.

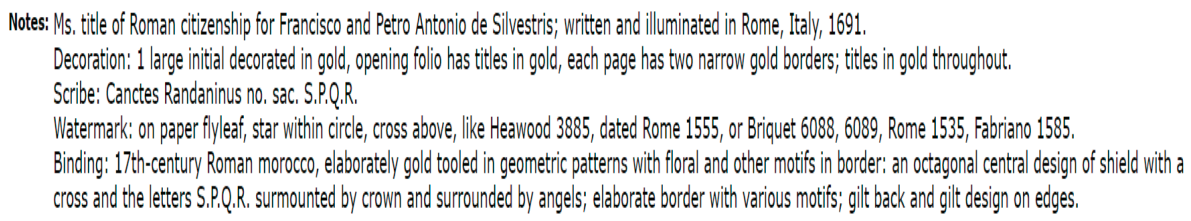

Slika 5. Primjer dijela kataložnog zapisa koji sadrži opis vodenog znaka iz kataloga Morgan Library \& Museum

Zaključno, u svim je navedenim primjerima opisa iz relevantnih međunarodnih kataloga stare i rijetke građe vidljivo da se podaci o vodenim znakovima, kad god je to moguće, navode u kataložnim opisima rukopisa i starih knjiga. Opravdano se može zaključiti da su podaci o vodenim znakovima sve uobičajeniji i vrijedan dio svakog opisa rukopisa i stare knjige. Tim se podacima informacijski obogaćuju ti zapisi čime se pridonosi boljem razumijevanju rukopisa i stare knjige, kao i razumijevanju konteksta u kojem su nastali ili bili upotrebljavani.

\subsection{Povezivanje podataka o vodenim znakovima i podataka o rukopisi- ma i tiskanim knjigama u kojima su pronađeni}

Ono što je osobito važno jest potreba za povezivanjem podataka o vodenom znaku na papiru s podacima o rukopisu ili staroj knjizi na kojoj je pronađen jer je to način na koji se osigurava kontekstualizacija obaju opisa i kojim se omogućuje informacijsko obogaćivanje podataka o rukopisu, kao i onih o vodenom znaku. Takvo povezivanje kroz svoj projekt osobito potiče Austrijska akademija znanosti. U sklopu projekta „Vodeni znakovi srednjeg vijeka“ koji je 1999. godine počela provoditi uz Odjel za paleografiju i kodikologiju austrijskog Instituta za medievistiku digitalizirani su i opisani vodeni znakovi. Projekt je uz opis i digitalizaciju vodenih znakova fokus postavio upravo na povezivanju podataka o vodenim znakovima s podacima o rukopisima u kojima su vodeni znakovi pronađeni. U sklopu projekta izrađena je posebna baza podataka koja je usklađena s informacijskim sustavom za opis rukopisa koji se kao značajan projekt razvija od 2010. godine pod pokroviteljstvom Njemačke zaklade za znanost, a cilj mu je stvaranje skupnog informacijskog sustava za vodene znakove velikog broja njemačkih ustanova, iz- 
među ostalih Bavarske knjižnice, Njemačke nacionalne knjižnice i knjižnica u Berlinu, Stuttgartu, Leipzigu i dijela austrijskih knjižnica. Sustav koji je oblikovan u sklopu projekta ima za cilj omogućavanje unosa digitalnih reprodukcija vodenih znakova te metapodataka, uključujući podatke o motivu i o rukopisu u kojem je vodeni znak sadržan. Sustav se temelji na decentralizaciji, odnosno nastoji preuzeti ulogu skupnog kataloga kako bi se omogućila značajnija upotreba vodenih znakova ne samo u datiranju nedatiranih rukopisa već i u ostalim povijesnim, povijesno-umjetničkim, filološkim, muzikološkim i drugim istraživanjima. Baza se izvedbeno oslanja na rješenja baze Piccard-online, no tomu dodaje i neka napredna proširenja, kao što je geografsko mapiranje i vizualizacija podataka o vodenim znakovima. Kako bi se povećala informacijska snaga baze, u nju su integrirani i podaci iz baze Piccard-online. U prvoj fazi digitalizirano je 103000 vodenih znakova, a u drugoj se očekuje još oko 28000 . Važno je napomenuti inzistiranje na povezivanju baze vodenih znakova s bazama rukopisa kako bi se povećala informacijska i istraživačka snaga baze.

\subsection{Navođenje podataka o vodenim znakovima u hrvatskim katalozima}

U Hrvatskoj se podaci o vodenim znakovima, nažalost, uobičajeno ne navode u kataložnim opisima stare i rijetke građe. Budući da ponekad izostaje i podatak o podlozi na kojoj su rukopis ili stara knjiga napisani, izostanak podatka o vodenim znakovima u katalozima upućuje na podzastupljenost uporabe filigranologije i nalaza proizašlih iz filigranoloških istraživanja pri kataložnom opisu stare knjige. Unatoč tomu što se kodikološki opis i istraživanja papira i vodenih znakova provode u laboratorijima za zaštitu u sklopu arhiva i većih knjižnica, npr. Nacionalne i sveučilišne knjižnice u Zagrebu, ${ }^{33}$ dokumentacija o tim istraživanjima vodi se odvojeno te podaci o vodenim znakovima i o podlozi rukopisa i starih knjiga nisu ni prisutni u kataložnim zapisima, ni dostupni korisnicima.

Pravilnik za opis i pristup građi u knjižnicama, arhivima i muzejima ${ }^{34}$ zasigurno radi iskorak u ovom području s obzirom na to da nudi element Materijal podloge (4.9) kroz koji se može u strukturiranom obliku, pomoću nadziranog rječnika, iskazati vrsta materijala podloge, i Napomenu o materijalu i tehnici (4.12), u kojoj se deskriptivno može iskazati podatak o postojanju vodenog znaka. Pravilnikom je put za bilježenje podataka o vodenom znaku priređen i kroz odnos između agenta i pojavnog oblika, pri čemu je predviđen agent Proizvođač papira definiran kao ,agent koji je proizveo papir tiskanog ili rukopisnog sveska, lista ili skupa

\footnotetext{
33 Više o tome vidjeti u: Štefanac, T. Metode i postupci istraživanja i obrade vodenih znakova na građi iz fonda Nacionalne i sveučilišne knjižnice u Zagrebu. // Arhivi, knjižnice, muzeji: Mogućnosti suradnje u okruženju globalne informacijske infrastrukture 23(2020), str. 219-234.

34 Pravilnik za opis i pristup građi u knjižnicama, arhivima i muzejima. Zagreb: Hrvatski državni arhiv: Muzejski dokumentacijski centar: Nacionalna i sveučilišna knjižnica u Zagrebu, 2021. [citirano: 2021-08-20]. Dostupno na: https://pravilnik.kam.hr.
} 
listova“". ${ }^{35}$ Tako se omogućuje uspostavljanje odnosa između proizvođača papira koji se najčešće identificira uz pomoć vodenog znaka na papiru i jedinice građe koju opisujemo. Prema Pravilniku (A 6.1.1.3) moguće je vodeni znak opisati kao samostalno djelo. To je u skladu s opisom vodenih znakova kakav je predložen u sklopu projekta „Pisana baština“. ${ }^{36}$ Dodatno, Pravilnikom se uvodi proizvođač papira kao validni agent, a podaci o agentu bilježe se kroz pristupnice (usvojene i varijantne) te identifikatore, čemu se dodaju i ostali podaci koji agenta dodatno identificiraju i smještaju ga u vremenski i prostorni kontekst, a ti se podaci o građi povezuju s podacima o agentima koji su na neki od načina odgovorni za njezin nastanak ili su na neki od načina sudjelovali u njezinu životnom ciklusu. Time se omogućuje da se preko agenta strojno povežu zapisi za rukopis ili staru knjigu koja je pisana ili tiskana na papiru s proizvođačem toga papira. ${ }^{37}$ Slijedeći propise Pravilnika moguće je izraditi zapis vodenog znaka, i to u skladu s aplikacijskim profilom kakav je predložen u projektu „Pisana baština“ ${ }^{\text {“38 }}$ i njegovim proširenjima ovisno o detaljnosti opisa, te taj opis povezati s opisom za staru knjigu ili rukopis putem podatka o proizvođaču papira. Bilo bi korisno i to da se unošenje podatka o vodenom znaku u kataložni opis stare i rijetke građe preporuči kroz svojevrsne upute o opisu stare knjige.

Iako UNIMARC format omogućuje bilježenje podatka o vodenom znaku u kataložnom zapisu stare knjige i rukopisa, taj se podatak navodi kao kodirani podatak i upućuje tek na to nalazi li se vodeni znak na papiru opisivane knjige ili ne. Dakako, taj podatak upravo u kodiranom obliku ima izuzetnu vrijednost pri strojnim obradama i analizama, ali nije prikazan korisnicima u kataložnom zapisu. Isto tako bilježenje podatka o vodenom znaku u napomeni kataložnog zapisa, ako je prisutno, informativno je i korisno, no s obzirom na to da nije riječ o strukturiranim podacima, takvim se navođenjem ne omogućuje strojno prepoznavanje i upravljanje tim podacima.

Budući da se vodeni znakovi opisuju prema međunarodno uvriježenim pravilima te da se za njihov opis koriste posebni katalozi koji su u današnje vrijeme u pravilu online dostupni i izvedeni tako da su elementi opisa većinom strukturirani, kao što je slučaj i s opisom rukopisa, postoje preduvjeti za povezivanje podataka iz kataloga vodenih znakova s onima iz kataloga stare i rijetke građe.

35 Dodatak F: Uloge agenata u odnosu na jedinicu građe. Uloga agenta u odnosu pojavni oblik agent. Proizvođač. Proizvođač papira. // Pravilnik za opis i pristup građi u knjižnicama, arhivima i muzejima. Zagreb: Hrvatski državni arhiv: Muzejski dokumentacijski centar: Nacionalna i sveučilišna knjižnica u Zagrebu, 2021. [citirano: 2021-08-20]. Dostupno na: https://pravilnik.kam. hr/index.php?action=append $\&$ id= 33 .

36 Usp. Tomić, M.; Grzunov. L.; Eškinja, Ž. Nav. dj., str. 29.

37 Poglavlje 7. Identifikacija i opis agenta. // Pravilnik za opis i pristup građi u knjižnicama, arhivima i muzejima. Zagreb: Hrvatski državni arhiv: Muzejski dokumentacijski centar: Nacionalna i sveučilišna knjižnica u Zagrebu, 2021. [citirano: 2021-08-20]. Dostupno na: https://pravilnik. kam.hr/index.php?action=chapter\&id $=18$.

38 Usp. Tomić, M.; Grzunov. L.; Eškinja, Ž. Nav. dj., str. 29. 


\section{Prijedlog načina povezivanja kataloga vodenih znakova i kataloga rukopisa: Primjer portala GlagoLab}

U sklopu projekta „Pisana baština“"39 koji se provodi u Centru za istraživanje glagoljaštva Sveučilišta u Zadru u suradnji s Vestigia institutom za istraživanje rukopisa Sveučilišta u Grazu u Austriji posebno se promišljalo o uključivanju podataka o vodenim znakovima u opise rukopisa uz pomoć povezivanja kataloga rukopisa i kataloga vodenih znakova. Tako se nastoji informacijski obogatiti opis rukopisa i pružiti nove istraživačke mogućnosti znanstvenicima koji istražuju rukopise, kao i onima koji istražuju vodene znakove. U sklopu projekta provodi se dodatni projekt čiji je cilj istraživanje, digitalizacija i opis vodenih znakova na papiru glagoljskih rukopisa zadarskog područja, pod nazivom „Izrada kataloga vodenih znakova rukopisa zadarskog područja od 13. do 19. st.“", ${ }^{40}$ a unutar toga se projekta osmislio model integracije kataloga rukopisa i kataloga vodenih znakova kako bi se informacijski obogatili podaci o glagoljskim rukopisima zadarskog područja, a potom i bolje interpretirali.

U okvirima projekta izrađen je i nadopunjuje se GlagoLab: portal i digitalni laboratorij za suradnička istraživanja i promicanje hrvatskog glagoljaštva ${ }^{41}$ na kojem se nalazi katalog glagoljskih rukopisa ${ }^{42}$ i katalog vodenih znakova koji su pronađeni na papiru glagoljskih rukopisa pod nazivom VoZnaZD. ${ }^{43}$ Portal je izrađen $\mathrm{u}$ informacijskom sustavu Indigo ${ }^{44}$, a za opis rukopisa koristi se strojno čitljiv format UNIMARC te se nastoje implementirati odredbe Pravilnika za opis i pristup građi u knjižnicama, arhivima i muzejima. Katalog vodenih znakova izgrađen je tako da se za opis vodenog znaka koriste važeći međunarodni uzusi i smjernice za opis. Oba kataloga uz metapodatke sadrže i digitalne reprodukcije rukopisa i vodenih znakova. Pri tome svaki zapis vodenog znaka u bazi VoZnaZD prate dvije digitalne reprodukcije vodenog znaka, i to jedna reprodukcija bez mjera i jedna s apliciranim svim standardnim mjerama vodenog znaka te shema kodikološke strukture kodeksa u kojem se nalazi vodeni znak s posebno naznačenom pozicijom vodenog znaka koji se nalazi u navedenom kodeksu. ${ }^{45}$

\footnotetext{
39 Više o projektu u: Renhart, E.; M. Tomić. Nav. dj., str. 222-267.

40 Projekt je financirala Zaklada Hrvatske akademije znanosti i umjetnosti godine 2018. te Vestigia institut za istraživanje rukopisa Sveučilišta u Grazu u Austriji.

${ }^{41}$ Portal GlagoLab: portal i digitalni laboratorij za suradnička istraživanja i promicanje hrvatskog glagoljaštva. [citirano: 2021-08-20]. Dostupno na: https://glagolab.unizd.hr.

42 Portal GlagoLab. Katalog rukopisa. [citirano: 2021-08-20]. Dostupno na: https://glagolab.unizd.hr/?pr=1\&filter=10237.

43 Portal GlagoLab. Katalog vodenih znakova. [citirano: 2021-08-20]. Dostupno na: https://glagolab.unizd.hr/?pr=1\&filter=10239.

44 Indigo: Hybrid repository platform based on semantic technologies. [citirano: 2021-08-20]. Dostupno na: http://www.eindigo.net.

45 Više o projektu „Izrada kataloga vodenih znakova rukopisa zadarskog područja od 13. do 19. st.“, o opisu vodenih znakova u bazi podataka VoZnaZD te aplikacijskom profilu za opis rukopisa i dodacima
} 
Upravo shema kodikološke strukture kodeksa u kojem je vodeni znak pronađen jedan je od elemenata kojima se informacijski obogaćuje opis vodenog znaka i kojim se stvaraju preduvjeti za potpunije razumijevanje kodeksa u kojem se vodeni znak nalazi. Naime takva shema svraća pozornost na to da je vodeni znak pronađen u konkretnom kodeksu za koji je onda moguće utvrditi je li u kodeksu upotrijebljen samo jedan ili pak više vrsta papira, kojim poretkom i u kojem formatu, a dodatno se utvrđuje i razdoblje kada je proizveden papir itd. Takve mogućnosti otvaraju put za mnoga daljnja istraživanja rukopisa, zbog čega je u sklopu projekta odlučeno da se kataložni zapisi za rukopise i oni za pripadajuće vodene znakove moraju povezati kako bi se uvidom u oba povezana zapisa, odnosno zapisa za kodeks i za vodeni znak koji je u njemu pronađen, ostvarile pretpostavke za daljnja istraživanja rukopisa i pisane baštine te konteksta i značajki njihova razvoja.

Razlog više za odluku o povezivanju podataka o vodenim znakovima s onima o rukopisima leži u tome što se analizom kodeksa pri digitalizaciji i opisu vodenog znaka dolazi do saznanja o strukturi kodeksa koja su važna pri opisu rukopisa i koja bibliografima taj opis olakšavaju i upotpunjuju. Naime shema kodikološke strukture kodeksa uobičajena kod opisa vodenih znakova katalogizatoru rukopisa omogućuje jasniji uvid u strukturu kodeksa, raspored i veličinu svežnjića od kojih je kodeks sačinjen te olakšava izradu materijalnog opisa kodeksa. Materijalni opis obvezan je dio svakog opisa rukopisa, a sastoji se od tzv. kolacije, odnosno formulom iskazane strukture knjižnog bloka. ${ }^{46}$ Kolacija iskazana propisanom formulom stoga je upisana u podnožje sheme kodikološke strukture kodeksa koja se prilaže uz opis vodenog znaka te ju katalogizator pri opisu rukopisa može lako prenijeti u kataložni opis. Tako se pri opisu vodenog znaka uzimaju u obzir i one značajke opisa koje bi mogle biti iskorištene za opis rukopisa u kojem je vodeni znak pronađen. S obzirom na to da se katalog rukopisa i katalog vodenih znakova u Centru za istraživanje glagoljaštva izrađuju u istom informacijskom sustavu, Indigu, a uzimajući u obzir potrebu uključivanja podataka o vodenom znaku u opis rukopisa i obrnuto, odlučeno je povezati te dvije baze, što je i provedeno.

Kako bi se u opisu rukopisa ukazalo na to da je u njemu sadržan vodeni znak, zapis za rukopis povezan je sa zapisom za vodeni znak koji se u njemu nalazi, pri čemu je u samom dnu kataložnog zapisa za rukopis korisniku vidljiv element $S a$ drži vodeni znak, u kojem je istaknut naziv vodenog znaka. Naziv vodenog znaka ujedno je i hiperveza prema samom opisu vodenog znaka u katalogu VoZnaZD (slika 6).

kataložnom zapisu za opis vodenih znakova, načinu i primjerima prikaza sheme kodikološke srukture i opis učinkovitosti takva prikaza vidjeti u: Tomić, M., L. Grzunov, Ž. Eškinja. Nav. dj.

46 Više o materijalnom opisu rukopisa, formulama za kolaciju te uopće značajkama opisa rukopisa u skladu s međunarodnim uzusima opisa rukopisa i s Pravilnikom za opis i pristup građi u knjižnicama, arhivima i muzejima vidjeti u: Tomić, M. Katalogizacija starih rukopisa uporabom Pravilnika za opis i pristup građi u arhivima, knjižnicama i muzejima na primjeru zbirke glagoljskih kodeksa Arhiva Zadarske nadbiskupije. // Arhivi, knjižnice, muzeji: Mogućnosti suradnje u okruženju globalne informacijske infrastrukture 21(2018), str. 189-231. 


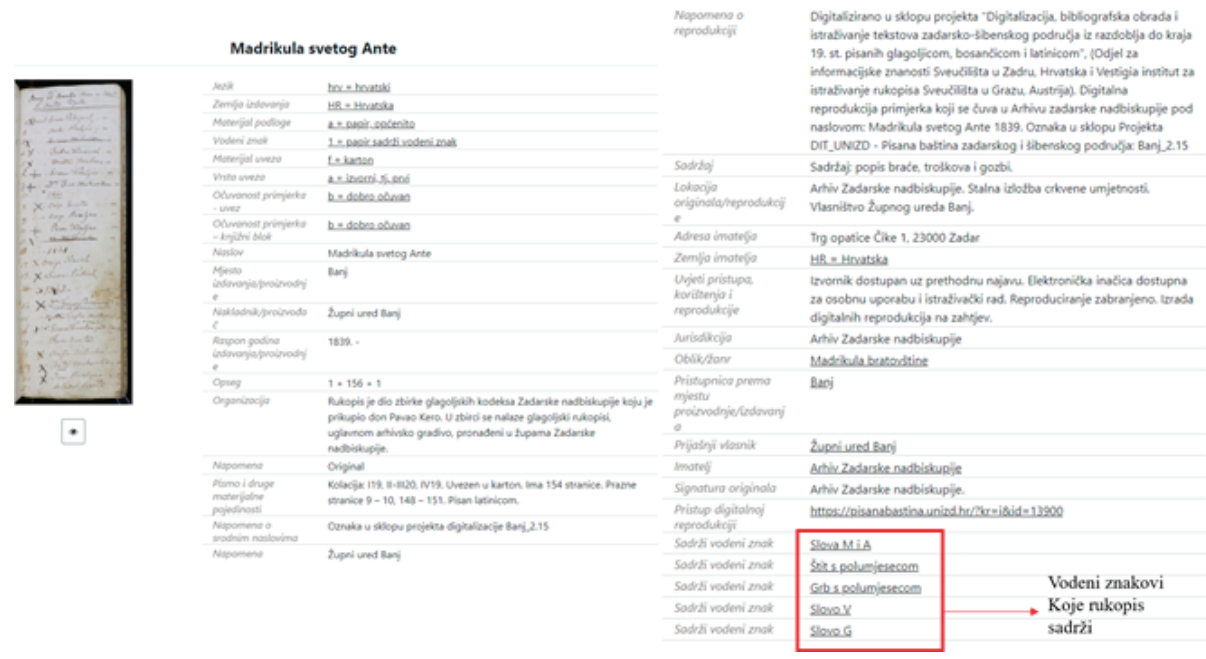

Slika 6. Opis rukopisa Madrikula svetog Ante (Arhiv Zadarske nadbiskupije, HRAZDN-88) s vidljivim popisom vodenih znakova koje sadrži

Uvidom u opis vodenog znaka koji se u rukopisu nalazi korisnik dobiva podatke o tom vodenom znaku, a ujedno mu je vidljiva i shema kodikološke strukture kodeksa u kojem se taj vodeni znak nalazi. Iz strukture prikazane u primjeru za vodeni znak za slova $M$ i $A$ (slika 7) vidljivo je da je riječ o kodeksu koji se sastoji od četiriju svežnjića, koji sadrže čak pet različitih vrsta papira. Time se značajno obogaćuje informacija i o rukopisu te upućuje istraživače na daljnja istraživanja bilo ostalih kodeksa koji su izrađeni u mjestu Banj, kao što je kodeks Madrikula svetog Ante iz ovog primjera, ili pak uopće kodikoloških struktura madrikula nastalih na području Zadarske nadbiskupije i sl.

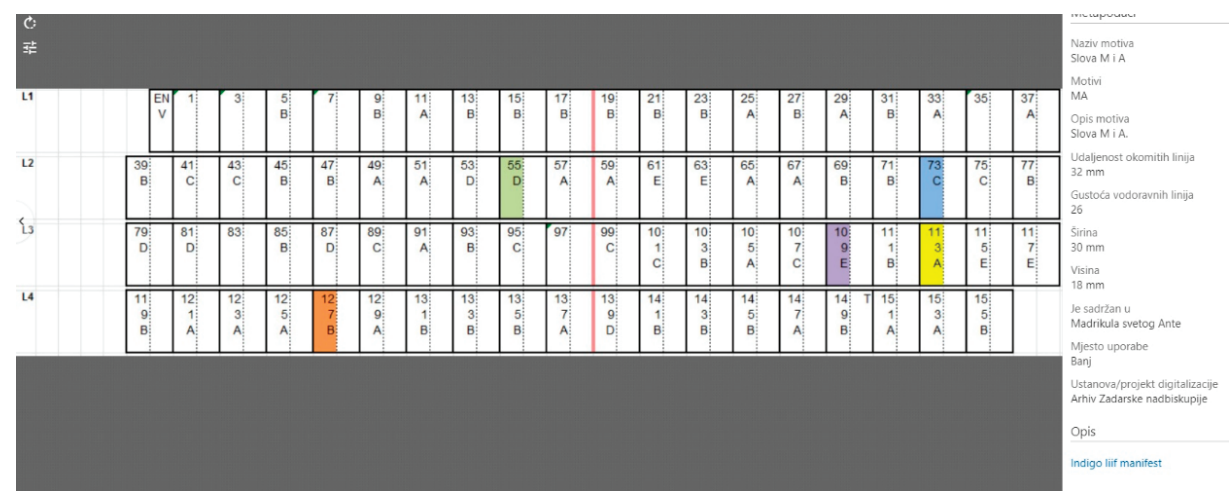

Slika 7. Opis vodenog znaka Slova $M$ i A u katalogu vodenih znakova VoZnaZD. Prikaz sheme kodikološke strukture kodeksa u kojemu je sadržan vodeni znak 
U sklopu projekta izrađen je model povezivanja kataloga rukopisa i kataloga vodenih znakova. Model se temelji na ugrađivanju odabranih elemenata podataka bibliografskog opisa rukopisa, i to podataka o naslovu, mjestu i godini proizvodnje i ustanovi u kojoj se kodeks nalazi, u opis onog vodenog znaka koji se nalazi u navedenom rukopisu (tablica 1 ).

Tablica 1. Elementi opisa rukopisa u kojem se vodeni znak nalazi koji se ugrađuju u kataložni opis vodenog znaka

\begin{tabular}{|l|l|l|}
\hline $\begin{array}{l}\text { Prikaz podataka o rukopisu } \\
\text { u kataložnom opisu vodenog } \\
\text { znaka (labele) }\end{array}$ & \multicolumn{2}{|l|}{$\begin{array}{l}\text { Polja/potpolja opisa rukopisa u UNIMARC formatu } \\
\text { koja se ugrađuju u opis vodenog znaka }\end{array}$} \\
\hline Je sadržan u: & & \\
\hline Naslov & $200 \$ a$ & Glavni stvarni naslov \\
\hline Godina & $210 \$ \mathrm{~d}$ & Godina izdavanja/raspačavanja \\
\hline Mjesto & $620 \$ \mathrm{~d}$ & Pristupnica prema mjestu izdavanja \\
\hline Imatelj & $850 \$ 3$ & Ustanova koja posjeduje jedinicu građe \\
\hline Signatura & $852 \$ \mathrm{a}$ & Signatura \\
\hline
\end{tabular}

U informacijskom sustavu Indigo izrađen je prototip toga modela u kojemu je provedeno ugrađivanje elemenata podataka bibliografskog opisa rukopisa u opis vodenog znaka (prema tablici 1). Time je omogućeno da su zapisi za rukopis (kataloga rukopisa) i za vodeni znak koji se u rukopisu nalazi (katalog vodenih znakova) strojno povezani, a korisniku su u zapisu za vodeni znak vidljivi najvažniji podaci o rukopisu u kojemu se nalazi vodeni znak, uključujući hipervezu prema cjelovitom zapisu u katalogu rukopisa (slika 8). Dodatno je omogućena i povratna veza, odnosno u zapisima u katalogu rukopisa korisnicima je vidljiv podatak o tome koji se vodeni znak u rukopisu nalazi, s hipervezom prema opisu vodenog znaka u katalogu rukopisa (slika 6). 


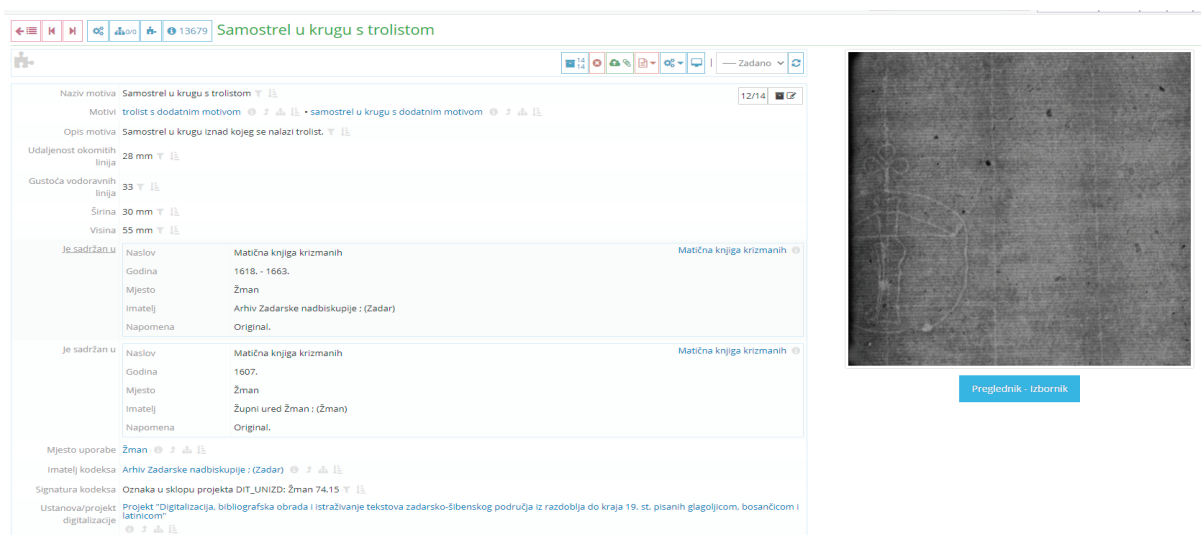

Slika 8. Prikaz prototipa modela integracije opisa vodenog znaka i opisa kodeksa u kojem se vodeni znak nalazi (opis vodenog znaka s ugrađenim elementima opisa rukopisa)

Povezivanjem kataložnih opisa rukopisa s opisima pripadajućih vodenih znakova omogućuje se stvaranje integrirane baze podataka koja omogućuje kontekstualizaciju vodenog znaka, ali i rukopisa te nudi istraživačima veći istraživački potencijal. Povezivanje dviju baza i korištenje zajedničkih baza autoriziranih pojmova ujedno omogućuje i okupljanje pri pretraživanju rukopisa koji su pisani na papiru istog proizvođača, što pak daje temelj za zaključke o vezama među pisarima i sl.

\section{Zaključak}

Uloga filigranologije u opisu rukopisa i stare knjige važna je, no u Hrvatskoj nedovoljno zastupljena. Ovim je radom na temelju pregleda literature prikazana njezina uloga te je primjerima dobre prakse pokazano da se podaci o vodenim znakovima $\mathrm{u}$ referentnim međunarodnim katalozima stare i rijetke građe unose $\mathrm{u}$ kataložne zapise. Dodatno, prikazom modela povezivanja podataka o rukopisima i vodenim znakovima kako se izvode na portalu GlagoLab, kao i prikazom modela integracije podataka iz dviju baza, dokazano je da podaci o vodenim znakovima značajno pridonose informacijskom obogaćivanju opisa rukopisa i stare knjige jer se na temelju njih može steći uvid i bolje razumjeti i interpretirati neke vanjske čimbenike i okolnosti izrade rukopisa, ali i naknadnih postupaka vezanih uz rukopis (npr. razdoblja kad je rukopis bio proizveden, kada je bio preuvezivan i sl.).

Ovim radom nastojalo se dokazati da bi uključivanje podataka o vodenim znakovima u opis stare i rijetke građe značajno pridonijelo vrijednosti takvih opisa i njihovoj ujednačenosti s međunarodnim referentnim katalozima. Dodatno, uključivanje 
tog podatka može potaknuti daljnja istraživanja iz kojih proizlaze mnoge mogućnosti, kao što su datiranja nedatiranih rukopisa, upoznavanje s okolnostima i obrascima nakladničke i tiskarske djelatnosti, trgovačkih putova papira, ali i s brojnim drugim pitanjima vezanim uz pisanu baštinu. Poticanje primjene filigranologije pri opisu stare i rijetke građe i uključivanja podataka o vodenim znakovima u kataložni opis stare i rijetke građe potaknulo bi i primjenu filigranologije u datiranju, određivanju bibliografskih formata, ali i uopće boljem poznavanju stare knjige.

Radom je pokazana opravdanost uključivanja podataka o vodenim znakovima u kataložni opis stare i rijetke građe, a nakana mu je i potaknuti knjižničnu zajednicu na uključivanje podataka o vodenim znakovima u kataložni opis stare i rijetke građe kako bi se opis obogatio podacima važnim za istraživačku i znanstvenu zajednicu, osobito za bibliografe i ostale istraživače stare i rijetke građe i povijesti knjige. Naime osim opravdanog zaključka da podaci o vodenim znakovima mogu pomoći i pri datiranju i detektiranju obrazaca proizvodnje rukopisa, ali i pri utvrđivanju značajki materijalnog opisa, kao što je bibliografski format ili pak (pre) uvez, nedostatak tih podataka u opisu rukopisa i starih knjiga može uzrokovati opravdano nezadovoljstvo suvremenih korisnika, osobito onih koji su posebno zainteresirani za rukopise i stare knjige i njihove materijalne osobitosti, ali i obrasce te kontekst njihove proizvodnje, trgovinske i druge veze tiskarskih radionica ili pisarnica u kojima su nastale i sl.

Model povezivanja podataka o glagoljskim rukopisima i u njima pronađenim vodenim znakovima kroz zajednički informacijski sustav Indigo kakav je osmišljen u sklopu projekta "Pisana baština" ima nakanu pridonijeti daljnjim istraživanjima glagoljskih rukopisa zadarskog područja i konteksta njihova nastanka i uporabe, ali i istaknuti mogućnosti uporabe strukturiranih baza podataka, osobito knjižničnih kataloga pri istraživanjima u području humanističkih znanosti, što je jedan od istraživačkih smjerova koji se razvijaju u području digitalne humanistike.

Način povezivanja zapisa o rukopisima i vodenim znakovima prikazan u ovom radu omogućuje po analogiji povezivanje i drugih raznorodnih strukturiranih podataka o pisanoj baštini te značajno pridonosi i istraživanjima u području filigranologije i onima u području kodikologije, povijesti knjige i pisane baštine uopće. Valja na koncu istaknuti da je na ovaj način ne samo omogućeno jasnije i strukturiranije uključivanje podataka o vodenim znakovima u opis rukopisa nego i rudarenje i vizualizacija podataka o vodenim znakovima, čiji rezultati mogu pridonijeti boljem poznavanju rukopisa i razvoja pisane kulture uopće. 


\section{LITERATURA}

Briquet, C. M. Les Filigranes: Dictionnaire historique des marques du papier dés leurs apparition vers jusqu'en 1600. Geneva: A. Jullien, 1907.

Bidwell, J. The study of paper as evidence, artefact, and commodity. In Peter Davison (ed.), The Book encompassed: Studies in twentieth-century bibliography (Pp 69-82). Cambridge: Cambridge University Press, 1992.

Bland, M. A. Guide to early printed books and manuscripts. Oxford: Wiley-Blackwell, 2013.

BO - Briquet Online. [citirano: 2021-03-04] Dostupno na: http://briquet-online.at.

Harris, N. Paper and watermark as bibliographical evidence. Lyon: Institut d' Histoire du Livre, 2017.

Hellinga, L. A meditation on the variety in scale and context in the modern study of the early printed heritage. // The papers of the Bibliographical Society of America 92, 4(1998), 401-426.

Hobson, A. R. A. Some sixteenth-century buyers of books in Rome and elsewhere. // Humanistica Lovaniensia: Journal of Neo-Latin Studies 34A(1985), 65-75.

Hunter, D. Papermaking: The History and technique of an ancient craft. New York: Dover Publications, 2016.

Indigo: Hybrid repository platform based on semantic technologies. [citirano: 2021-0604] Dostupno na: http://www.eindigo.net.

Institut d' historie du Livre. Paper Studies. [citirano: 2020-06-25]. Dostupno na: ihl. enssib.fr/analytical-bibliography-an-alternative-prospectus/paper-studies.

Internatioanl Association of Paper Historians. [citirano: 2021-03-04] Dostupno na: http://www.paperhistory.org/Watermark-catalogues.

International Standard for the Registration of Papers with or without Watermarks. Version 2.1.1. / International Association of Paper Historians, 2013. [citirano: 2020-0620]. Dostupno na: http://www.memoryofpaper.eu/products/IPHN2.1.1_en.pdf.

Needham, P. Allan H. Stevenson and the bibliographical uses of paper. // Studies in Bibliography, 47(1994), 23-64. [citirano: 2021-03-04] Dostupno na: https://www.jstor.org/stable/40371991.

Portal GlagoLab. Katalog vodenih znakova. [citirano: 2021-08-20]. Dostupno na: https://glagolab.unizd.hr/?pr=1\&filter=10239.

Portal GlagoLab. Katalog rukopisa. [citirano: 2021-08-20]. Dostupno na: https://glagolab.unizd.hr/?pr=1\&filter=10237.

Pravilnik za opis i pristup građi u knjižnicama, arhivima i muzejima. Zagreb: Hrvatski državni arhiv: Muzejski dokumentacijski centar: Nacionalna i sveučilišna knjižnica u Zagrebu, 2021. [citirano: 2021-08-20]. Dostupno na: https://pravilnik.kam.hr. 
Renhart, E.; M. Tomić. Digitalizacija, bibliografska obrada, istraživanje i komuniciranje zadarske pisane baštine. // Arhivi, knjižnice, muzeji: Mogućnosti suradnje u okruženju globalne informacijske infrastrukture 20(2017), 222-267.

Štefanac, T. Metode i postupci istraživanja i obrade vodenih znakova na građi iz fonda Nacionalne i sveučilišne knjižnice u Zagrebu. // Arhivi, knjižnice, muzeji: Mogućnosti suradnje u okruženju globalne informacijske infrastrukture 23(2020), 219-234.

Tanselle, T. The Bibliographical description of paper. // Studies in Bibliography, 24(1971), 27-67.

Tomić, M. Katalogizacija starih rukopisa uporabom Pravilnika za opis i pristup građi u arhivima, knjižnicama i muzejima na primjeru zbirke glagoljskih kodeksa Arhiva Zadarske nadbiskupije. // Arhivi, knjižnice, muzeji: Mogućnosti suradnje u okruženju globalne informacijske infrastrukture 21(2018), 189-231.

Tomić, M.; L. Grzunov; Ž. Eškinja. Mogućnosti i pretpostavke filigranoloških istraživanja u kontekstu istraživanja zadarske glagoljske baštine. // Vjesnik bibliotekara Hrvatske 63, 1/2(2020), 1-29.

Wagner, B. Introduction. // Early printed books as material objects: Proceedings of the Conference Organized by the IFLA Rare Books and Manuscripts Section, Munich, 19-21 August 2009. / edited by B. Wagner and M. Reed. Hague: De Gruyter Saur, 2010.

Williams, W. P.; C. S. Abbott. An introduction to bibliographical and textual studies. Kindle ed. New York: The Modern Language Association of America, 2009. 